\title{
Learning Behavior of Horse Colts: a Case Study of Nepal Cavalry Barrack, Singha Durbar, Kathmandu, Nepal
}

\author{
Kamal K.C. and N.B. Singh \\ Central Department of Zoology, Tribhuvan University, Kirtipur, Nepal \\ E-mail:kamal.kc50@yahoo.com and nanda_nepal@yahoo.com
}

\begin{abstract}
This paper tries to study learning ability behaviors of horse colts in Nepal Cavalry Barrack (NBC), Singha Durbar, Kathmandu. The learning ability of horse colts has been found different behaviors during learning stages. The horses showed different behaviors like fighting, flighting, kicking and biting during trainings. There was no difference of learning ability among three months age of colts. The Learning Ability Index (LAI) has been found as 56, 55, 54, 55, 51 and 64 for the colts A, B, C, D, E and F, respectively.
\end{abstract}

Key words: Learning behavior, different stages, cavalry.

\section{INTRODUCTION}

The horse (Equus ferus caballus Linnaeus 1758) is one of two extant sub-species of Equus ferrus (Ishida 1995). A male horse under the age of four is commonly called as colt (Ensminger 2007). Many horses will become difficult to manage if they are isolated, but with training, horses can learn to accept a human as a companion, and thus be comfortable away from other horses (Clarkson 2007). They communicate in various ways, including vocalizations such as nickering or whinnying, mutual grooming, and body language and also may develop stable vices, an assortment of bad habits, mostly stereo-types of psychological origin, that include wood chewing, wall kicking, weaving and other problems (Clarkson 2007). The LAI (Fiske \& potter 1979) is used to test the learning ability between different colts. The ability of horse to learn has not been extensively studied. Much reported research has dealt with the horse's intelligence rank with respect to other domestic animals (Katz 1927). Few studies have been conducted to investigate individual variations in learning ability among horses (Kratzer 1971).

Information on individual difference in learning ability of horses, especially among young horses, could provide a valuable tool for assessing the future trainability of horses. Discrimination reversal learning has been shown effective in measuring learning ability in many species and has been found to be a feasible technique for measuring learning ability in individual horses. A horse could respond to different fixed ratios and fixed interval positive reinforcement schedules (Myers \& Mesker 1960). The horse can learn each new problem (McCall et al. 1981). The horses are very good at discriminating stimuli (Pfungst 1907). Both positive and negative reinforcements connect the specific stimulus (Tarpy 1975). Equine learning ability is similar under primary positive and primary negative reinforcement (Haag et al. 1980). Younger horses show faster rate of learning (Mader \& Price 1980). Early handling of horses has a positive influence on their subsequent learning ability (Heird et al. 1986). The horse can learn bad habits from each other (Baer et al. 1983). Excellent memory and recall ability have been documented in the horse (Nicol 1995). There was no difference in learning ability during three months of age among colts (Williams et al. 2002).

\section{MATERIALS AND METHODS}

\section{Study Area}

This study was conducted in NCB at Singha Durbar, Kathmandu, Nepal. The total counted individuals of horses during the study were 101 among them 50 were gelds, 6 colts, 13 stallions, 4 fillies and 28 mares in $\mathrm{NCB}$, and of them a total of 6 colts were only used to assess and test their learning behavior and ability. The horses were tested in a rectangular horse school having $(60 \times 20 \times 3) \mathrm{m}^{3}$ dimensional space where $15 \mathrm{~cm}$ depth of ground floor were filled by sand, wood dust and horse dungs. Horse school was marked for training (Fig. 3). Data were collected from June-August, 2014 with different parameters (walking, obstacle walking and jumping). Each parameter was divided into three stages i.e. primary (learning stage of horse without carrying any seat and rider), secondary (learning stage of horse with carrying only seat) and tertiary (learning stage of horse by carrying rider). Aggressive behavior of horses like biting, kicking, flighting and fighting was counted as error in research. Horse was controlled by launging 
rash in primary and secondary stages but in tertiary stage was controlled by bridle. Walking trial was conducted in clockwise and anti-clockwise direction inside the horse school. Walking trial was observed in different steps like walk, troat, cantor and gallop. Obstacle walk was conducted outside the school in anti-cline and syn-cline path. Jumping trials were conducted inside horse school.

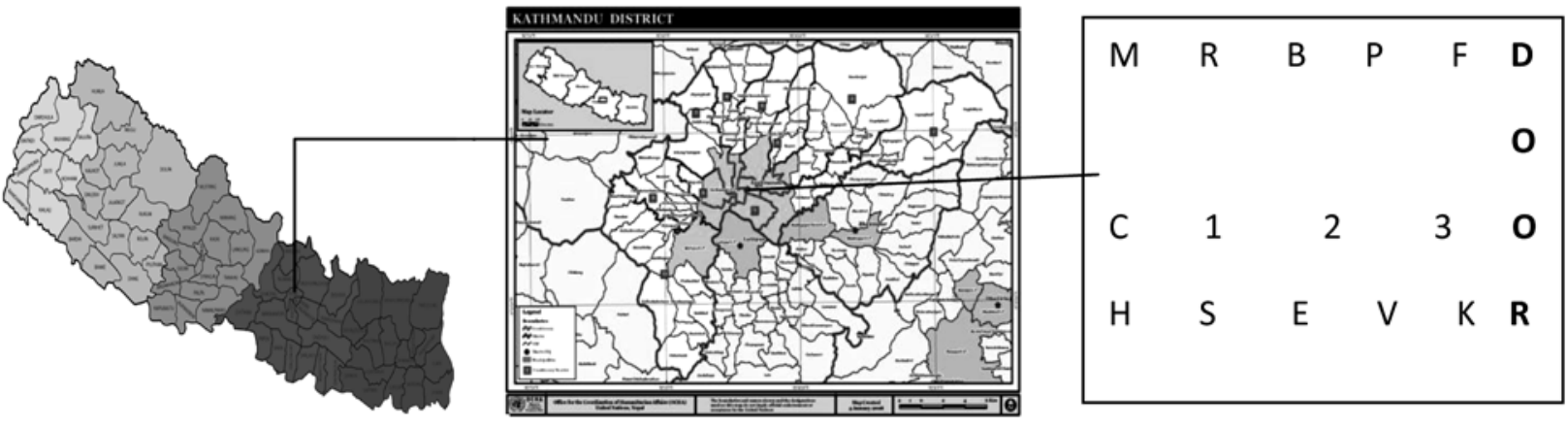

Fig. 1. Map of Nepal

Fig. 2. Map of Kathmandu

Fig. 3. Map of Horse school

Table 1. LAI of colts during walking, obstacle walking and jumping.

\begin{tabular}{|c|c|c|c|c|c|c|c|c|c|c|c|c|c|}
\hline \multirow[t]{2}{*}{ S.no } & \multirow[t]{2}{*}{ Colt } & \multicolumn{2}{|c|}{ Age } & \multicolumn{3}{|c|}{ Primary Stage } & \multicolumn{3}{|c|}{ Secondary stage } & \multicolumn{3}{|c|}{ Tertiary stage } & \multirow[t]{2}{*}{ Total } \\
\hline & & Years & Month & MT & $\mathrm{ME}$ & LAI & MT & $\mathrm{ME}$ & LAI & MT & ME & LAI & \\
\hline \multicolumn{14}{|c|}{ Walking } \\
\hline 1 & A & 3 & 2 & 23.7 & 8.4 & 5.02 & 83.07 & 5.53 & 1.51 & 84.6 & 8.4 & 0.98 & 7.51 \\
\hline 2 & B & 3 & 2 & 23.7 & 5.8 & 7.61 & 80.20 & 5.50 & 1.55 & 80.8 & 8.4 & 1.01 & 10.71 \\
\hline 3 & $\mathrm{C}$ & 3 & 0 & 23.7 & 8.4 & 5.01 & 80.13 & 5.50 & 1.54 & 77.2 & 5.5 & 1.58 & 8.13 \\
\hline 4 & $\mathrm{D}$ & 2 & 11 & 23.7 & 5.5 & 7.61 & 75.80 & 5.50 & 1.59 & 83.1 & 5.5 & 1.56 & 10.76 \\
\hline 5 & $\mathrm{E}$ & 2 & 9 & 23.7 & 8.4 & 5.01 & 80.80 & 5.50 & 1.54 & 77.6 & 5.5 & 1.58 & 8.13 \\
\hline 6 & $\mathrm{~F}$ & 2 & 8 & 23.3 & 8.4 & 5.01 & 80.60 & 5.53 & 1.56 & 75.5 & 5.5 & 1.62 & 8.19 \\
\hline \multicolumn{14}{|c|}{ Obstacle walking } \\
\hline 1 & $\mathrm{~A}$ & 3 & 2 & 4 & 6.2 & 39.89 & 6 & 5.53 & 30.12 & 7 & 5.47 & 26.13 & 96.14 \\
\hline 2 & B & 3 & 2 & 4 & 5.1 & 45.18 & 6 & 6.27 & 26.59 & 7 & 8.40 & 17.00 & 88.77 \\
\hline 3 & $\mathrm{C}$ & 3 & 0 & 4 & 5.7 & 43.60 & 6 & 8.40 & 19.84 & 7 & 5.53 & 25.81 & 89.25 \\
\hline 4 & $\mathrm{D}$ & 2 & 11 & 4 & 6.2 & 39.89 & 6 & 5.47 & 30.48 & 7 & 8.40 & 17.00 & 87.37 \\
\hline 5 & $\mathrm{E}$ & 2 & 9 & 4 & 8.4 & 29.76 & 6 & 8.4 & 17.00 & 7 & 5.47 & 30.48 & 77.24 \\
\hline 6 & $\mathrm{~F}$ & 2 & 8 & 4 & 5.53 & 45.18 & 6 & 5.47 & 30.48 & 7 & 6.27 & 39.89 & 115.5 \\
\hline \multicolumn{14}{|c|}{ Jumping } \\
\hline 1 & $\mathrm{~A}$ & 3 & 2 & 0 & 0 & 0 & 4.6 & 6.5 & 33.27 & 4.8 & 6.4 & 32.55 & 65.82 \\
\hline 2 & $\mathrm{~B}$ & 3 & 2 & 0 & 0 & 0 & 4.6 & 6.5 & 33.27 & 4.8 & 6.3 & 32.89 & 66.16 \\
\hline 3 & $\mathrm{C}$ & 3 & 0 & 0 & 0 & 0 & 4.6 & 6.1 & 35.44 & 4.8 & 6.5 & 31.88 & 67.32 \\
\hline 4 & $\mathrm{D}$ & 2 & 11 & 0 & 0 & 0 & 4.6 & 7.1 & 35.44 & 4.8 & 6.2 & 33.24 & 68.68 \\
\hline 5 & $\mathrm{E}$ & 2 & 9 & 0 & 0 & 0 & 4.6 & 6.2 & 34.69 & 4.8 & 6.1 & 33.96 & 68.65 \\
\hline 6 & $\mathrm{~F}$ & 2 & 8 & 0 & 0 & 0 & 4.6 & 6.2 & 35.06 & 4.8 & 5.8 & 35.51 & 70.57 \\
\hline
\end{tabular}

\section{RESULTS}

LAI is defined as the ratio of 1000 to the product of mean trial (M.T.) and mean error (M.E.) (Fiske \& Potter 1979). Symbolically,

Table 1 presents the LAI of six colts during walking, obstacle walking and jumping. LAI of colts during primary stage of walking showed that colt-B and colt-D were better learners than other colts. During secondary stage all colts showed same learning ability and at tertiary stage of walking colt-A and colt-B showed less learning ability than other colts. LAI of colts during primary stage of obstacle walking showed that colt-B was better learner than other colts. During secondary stage colt-A, colt-D and colt-F showed the better learning ability than colt-B, colt-C and colt-E. In tertiary stage colt-F showed the best learning ability of all others but least ability was observed in colt-B and colt-D. LAI of 
colts during primary stage of jumping showed that colt-C and colt-D were better learners than other colts. During secondary stage of jumping colt-E and colt-F showed better learning ability than other colts. The LAI value was calculated 56, 55, 54, 55, 51 and 64 for the colts A, B, C, D, E and F; respectively. The ages of colts A, B, $\mathrm{C}, \mathrm{D}, \mathrm{E}$ and $\mathrm{F}$ were 3 years 2 months, 3 years 2 months, 3 years 0 months, 2 years 11 months, 2 years 9 months and 2 years 8 months; respectively. All the colts were observed as similar learners but colt-F had higher value of LAI and less in colt-E.

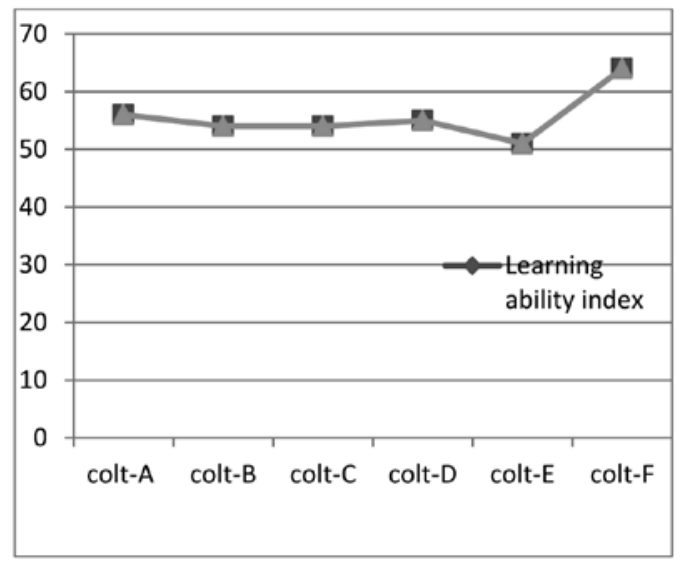

Fig. 4. Scatter diagram of LAI

\section{DISCUSSION}

Ensminger (2007) reported about strong flight-fight response of horses. Clarkson (2007) documented horses could learn to accept human. Leste-lessere (2009) explained about bad behavior of horses when they got more rest and the intelligent horse was the reflection of intelligent trainer. Myers and Mesker (1960) revealed horses could respond different positive reinforcements. McCall (1981) reported horse could learn each new problem. Pfungst (1907) documented horses had very good discriminating stimuli, it was clearly demonstrated horse kluge hans. The colts were observed every day to enter inside the school without any confusion. Trapy (1975) reported the positive and negative reinforcements connected with the specific stimulus, so that when the specific stimulus presented again there was greater chance of the horses making the correct responses. The colts were observed learning same skills either by reward or punishment. Hagg et al. (1980) reported Equine learning ability was similar under positive and negative reinforcements, it reported that horses learned better in both positive and negative reinforcements. Mader and Price (1980) reported younger had faster rate of learning, learning rate decreased as their age increased.
Baer (1983) reported horses learnt bad behavior from each other. Nicol (1995) documented recall ability of the horse. Williams et al. (2002) reported that there was no difference in learning ability at three months different age of horses.

\section{CONCLUSION}

The colts were observed remembering the past taught skills by trainers. There was no difference of learning ability among three months age of colts. The LAI value is calculated 56, 55, 54, 55, 51 and 64 for the colts A, B, C, D, E and F: respectively. The age of colts A, B, $\mathrm{C}, \mathrm{D}, \mathrm{E}$ and $\mathrm{F}$ was 3 years 2 months, 3 years 2 months, 3 years 0 months, 2 years 11 months, 2 years 9 months and 2 years 8 months; respectively. The LAI value of six colts was in similar range where 30 respondents gave interviews in which they explained that it was more difficult to teach geld than colt due to their aggressive behavior and strength. The colt learnt hardly and they showed different aggressive behaviors. About 80 percent of respondents explained the difficulty to teach colt during primary stage of learning. About 50 percent of respondents suggested that during secondary and tertiary stages they showed aggressive behaviors at first due to load on back of them. The average punishments given by the trainer for each colt was observed one time per day which got negative reinforcement. The trainers were observed giving sweets to colt average two times per day which got positive reinforcement one time per day. Biting behavior was observed one time per day, flighting behavior was observed more in primary stage than in secondary and tertiary stages where as it was observed average three times per day in primary stage but two times per day in secondary and tertiary stages. Kicking behavior was observed one time per day where colt-F learnt better than other colts. The LAI value of the colt-F was observed 64 which was the highest value of all the other colts suggesting the NCB for using better scientific technology for horse training.

\section{ACKNOWLEDGMENTS}

We would like to thank Prof. Dr. Ranjana Gupta, Head, Central Department of Zoology, T.U. for her academic and administrative coordination, the trainers and staffs of $\mathrm{NCB}$ for their cooperation and all the respondents who provided their valuable information.

\section{REFERENCES}

Baer, K.L., Potter, G.D., Friend, T.H., Beaver, B.V. 1983. Effect in learning of horses. Animal Ethology 11: 123.

Clarkson, N. 2007. Understanding horse intelligence. Horsetalk. pp. 71-73. 
Ensminger, E. 2007. Horses and Horsemanship. Cornell University press, Ithaca, p. 422.

Fiske J.C., Potter G.D. 1979. Discrimination Reversal learning in Yearling Horses. Journal of Animal Science 49: 583-588.

Heird, J.C., Whitaker, D.D., Bell, C.B., Ramsey, C.B., Lokey, C.E. 1986. The effects of handling of twoyears old horse. Animal Behavior 15: 15.

Haag, E.L., Rudman, R., Houpt, K.A. 1980. Learning and social dominace in ponies. Journal of Animal Science 50: 329.

Ishida, N., Oyunsuren, T., Mashima, S. Mukoyama, H., Salton, N. 1995. Mitochondrial DNA sequence of various species of the genus Equus with species reference to the phylogenetic relationship between przewalskii's wild horse and domestic horse. Journal of Molecular Evolution 41:180-188.

Katz, D. 1927. Animals and men: Studies in comparative psychology. Longman Green, London, England, p 212.

Kratzer, D.D. 1971. Learning in farm animals. Journal of Animal Science 32: 1268.

Lest-Lasserre, C. 2009. Horses Demonstrate Ability to Count in new study. The Horse: Blood-Horse Publications p. 212.
Mader, D.R., Price E.O. 1980. Discrimination learning in horse. Journal of Animal Science 50: 962.

McCall, C.A., Potter, G.D., Friend, T.H., Ingram, R.S. 1981. Learning ability in yearling horses. Journal of Animal Science 53: 928.

Myers, R.D., Mesker, D.C. 1960. Operant responding of horse. Animal Behaviour 3: 161.

Nicol, C.J., 1995. The social transmission of information and behavior. Animal Behavior Science 44: 79-98.

Pfungst, O. 1907. The behavior of domestic animal. William and Wilkins publication, Baltimore, $\mathrm{p}$ 332.

Tarpy, R.M. 1975. Basic principle of leaning. Animal Behavior Science 77: 112-123. W. arrer, J. 1962. Reversal learning by horse and raccoon. Journal of general Psychology. 100: 215

Williams, J.1., Friend, T.H., Toscano, M.N., Sisto-Burt, A., Nevill, C.H., 2002. The effect of early training sessions on the reactions of foals. Animal Behavior Science 77: 105-11. 